日植病報 $41 ： 453-460$ (1975)

Ann. Phytopath. Soc. Japan 41: 453-460 (1975)

\title{
Some Characteristics of the Heat-Induced Susceptibility Demonstrated in Powdery Mildew of Barley
}

\author{
Sei ji Ouchi*, Hachiro Oku*, Hideto Nakabayashi* \\ and Kazunori OkA* \\ 大内成志・奥 八郎・中林英人・岡 和徳：オオムギうどんこ病 \\ に打ける熱誘導感受性の特性について
}

\begin{abstract}
Heat predisposition effects were studied of barley powdery mildew by use of some compatible and incompatible combinations. Heat treatment above $45 \mathrm{C}$ rendered barley leaves susceptible to incompatible races, although the pattern of dose-responses differed from one combination to the other. Treatment at $50 \mathrm{C}$ suggested that the once-induced susceptibility is reduced by exposing leaves for longer time. Incompatible and nonpathogenic races established infection on heat-treated leaves with much higher efficiency comparing with compatible one, but never reached the level of the compatible race in terms of ESH frequency, suggesting that these races induce rejection reaction prior to the elongation of secondary hyphae. The heat-induced susceptibility disappeared about $24 \mathrm{hr}$ after heat treatment at the rate of a pseudo first-order reaction. Compatible combination is also affected by heat treatment, as was illustrated in significant increase of ESH frequency by the treatment at $45 \mathrm{C}$ and a retreat at $50 \mathrm{C}$-min.
\end{abstract}

(Received December 3, 1974)

\section{Introduction}

Since Salmon ${ }^{21,22)}$ found that heat treatment changed resistance of gramineous plants against powdery mildews, the effects of temperature on the development of disease syndrome have been the subject of various types of studies. It has been well established that thermal treatment of plants causes a remarkable change in their responses to pathogenic and nonpathogenic microorganisms ${ }^{1,3,4,7,8,10,11,25,27,29,30 \sim 32)}$, as could also be exemplified in the modifications of phenotypic expression of resistance genes ${ }^{13}$, ${ }^{15,16,23)}$, and more specifically, of the pattern of phytoalexin induction ${ }^{2,5,6,9,17,20)}$. These literatures suggest that the so-called 'heat predisposition' involves a general permission of cells or tissues against pathogen as well as nonpathogen. A few studies has, however, been conducted to elucidate the mechanism of this effect, in spite of the well characterized phenomenon.

In the light of these informations, the authors, in this communication, elucidate some characteristics of the heat-induced susceptibility in powdery mildews and discuss these in relation to the general patterns of infection establishment.

This work was partly supported by a grant in aid for specified project from the Ministry of Education (No. 811209).

* 岡山大学農学部 Faculty of Agriculture, Okayama University, Okayama, Japan. 


\section{Materials and methods}

Plants: Some cultivars of barley (Hordeum vulgare L.), genetically defined in terms of response to particular races of powdery mildew fungus were used throughout the experiments. These are Kobinkatagi (compatible to race 1), H.E.S. 4 (compatible to race $\mathrm{Hh} 4$, but incompatible to race 1), and an isogenic line (abbreviated to Isonig) derived from hybridization of Kobinkatagi and Hordeum spontaneum nigrum (immune to any race found in Japan). One cultivar of wheat (Triticum aestivum (L.) Thell spp. vulgare (Vill.) MK.), Norin No. 4, was also used for the culture of inoculum. Seeds of barley and wheat were soaked in tap water for $12 \mathrm{hr}$ and germinated on wet filter paper in a Petri dish. Germinated seeds of uniform size were embedded in vermiculite in a clay pot $(6 \mathrm{~cm}$ both in diameter and height $)$ and grown in a phytotron controlled at $20 \mathrm{C}$ for 8-10 days, supplying with sufficient quantity of Hyponex solution.

Fungi : Two races of Erysiphe graminis DC. f. sp. hordei Marchal, race 1 and Hh4, and one race of Erysiphe graminis DC. f. sp. tritici Marchal, t2, were used. Race 1 is compatible with Kobinkataki and incompatible with Isonig. Race Hh4 is compatible with H.E.S. 4, but incompatible with the others. The wheat race $\mathrm{t} 2$ is compatible with Norin No. 4, but nonpathogenic to barley cultivars employed in this work. These races were maintained on respective compatible cultivars by successive inoculations of 10 day-old seedlings with a $8-10$ days interval. For obtaining a synchronized inoculum, 10 day-old seedlings were inoculated with fresh conidia and incubated at $20 \mathrm{C}$ under artificial illumination (8,000 lux) for 8 days. The conidia formed on pustules were blown away and the fresh conidia emerged during subsequent $12 \mathrm{hr}$ were used as inoculum.

Inoculation: The conidia were inoculated on abaxial surface of the middle part of leaves, employing a soft hair brush.

Thermal treatment: Unless otherwise mentioned, thermal treatment was done $1 \mathrm{hr}$ prior to inoculation. Eight to 10 day-old seedlings in clay pot were placed in a dry air type incubator $(30 \times 30 \times 30 \mathrm{~cm}$ in size) controlled at certain temperature and incubated for definite period of time. Care was taken to keep the temperature constant during the treatment. Heat-treated seedlings were cooled at room temperature, inoculated, and then incubated in an illuminated phytotron controlled at $20 \mathrm{C}$ and 8,000 lux.

Assessment of infection establishment: Affinity indices were taken as parameters for the establishment of infection, as employed in previous papers ${ }^{18,19)}$. Inoculated area of leaves was cut out, fixed in a fixative (formaldehyde: glacial acetic acid: ethyl alcohol= 1:9:9) for $30 \mathrm{~min}$, dipped in $90 \%$ ethyl alcohol to extract chlorophylls, and stained with lactophenol cotton blue. Excess of stains was washed and specimens were observed under a microscope. Conidia which formed appressorium and those having elongated secondary hyphae were counted and the ratio of the latter to the total appressoriumformed conidia was represented as frequency of elongation of secondary hyphae (ESH frequency). The length of secondary hyphae ( $\mathrm{SH}$ length) was measured with a micrometer. Unless otherwise noted these indices were determined $48 \mathrm{hr}$ after inoculation. 


\section{Result}

\section{Heat effect as assessed with different incompatible combinations.}

Two incompatible combinations were chosen for estimation of the degree of susceptibility induced by thermal treatment. The effect of heat treatment on the infection establishment in these two combinations is summarized in Table 1 . No perceptible heat damage was observed under the experimental conditions. It is apparent that in both combinations primarily incompatible race can establish infection when the leaves were predisposed at a dose higher than $45 \mathrm{C}-20 \mathrm{~min}$, although pattern of dose-response slightly differed from one combination to the other. In the combination, Isonig-race 1, longer treatment at $45 \mathrm{C}$ seems to cause a slight retardation in both the $\mathrm{ESH}$ frequency and $\mathrm{SH}$ length. In the combination, Kobinkatagi-t2, the secondary hyphae on leaves treated at $45 \mathrm{C}-60 \mathrm{~min}$ was longer than those observed of leaves treated at $45 \mathrm{C}-20 \mathrm{~min}$, while no statistically significant difference could be detected of ESH frequencies between these two doses. Nevertheless in both combinations treatment at $50 \mathrm{C}-10 \mathrm{~min}$ gave rise to a significant decrease in both ESH frequency and SH length. Thus heat treatment at a higher temperature seems to exert a different effect from those elicited at lower temperature. It should be noted here that sporulation as observed under a microscope was quite restricted, if ever formed, on these heat-treated leaves.

Table 1. Heat-induced susceptibility as assessed with two different incompatible combinations

\begin{tabular}{|c|c|c|c|c|}
\hline \multirow[b]{2}{*}{ Combination } & \multicolumn{2}{|c|}{ Heat dosage } & \multicolumn{2}{|c|}{ Affinity indices } \\
\hline & $\begin{array}{c}\text { Temp } \\
\text { (C) }\end{array}$ & $\begin{array}{l}\text { Time } \\
(\min )\end{array}$ & $\begin{array}{c}\text { ESH frequency } \\
(\%)\end{array}$ & $\begin{array}{c}\text { SH length } \\
(\mu \mathrm{m})\end{array}$ \\
\hline \multirow{6}{*}{ Isonig-Race $1^{*}$} & \multicolumn{2}{|c|}{20 (Control) } & 0 & 0 \\
\hline & 30 & 20 & 0 & 0 \\
\hline & 45 & 20 & 10.6 & 60.8 \\
\hline & 45 & 60 & 8.2 & 50.6 \\
\hline & 50 & 5 & 19.0 & 53.4 \\
\hline & 50 & 10 & 10.5 & 44.8 \\
\hline \multirow{6}{*}{ Kobinkatagi-t 2} & \multicolumn{2}{|c|}{20 (Control) } & 0 & 0 \\
\hline & \multicolumn{2}{|l|}{30} & 0 & 0 \\
\hline & 45 & 20 & 16.8 & 34.8 \\
\hline & 45 & 60 & 12.1 & 57.1 \\
\hline & 50 & 5 & 10.8 & 39.8 \\
\hline & 50 & 10 & 6.3 & 27.6 \\
\hline
\end{tabular}

* Affinity indices were estimated $36 \mathrm{hr}$ after inoculation.

\section{Heat effect as assessed with different races}

If the thermal predisposition involves physiological conditioning of the cell toward general permission of primary symbiotic association of host and parasite, then the races with primarily different compatibilities will equally invade the cells of heat-treated leaves, provided they do not induce resistant reaction before the emergence of secondary 
Table 2. Heat-induced susceptibility as assessed with three different incompatible races*

\begin{tabular}{|c|c|c|c|c|}
\hline \multicolumn{2}{|c|}{ Heat Dosage** } & \multirow[b]{2}{*}{ Test Race } & \multirow[b]{2}{*}{$\begin{array}{c}\text { ESH Frequency*** } \\
(\%) \\
\end{array}$} & \multirow[b]{2}{*}{$\begin{array}{l}\text { SH Length } \\
\quad(\mu \mathrm{m})\end{array}$} \\
\hline $\begin{array}{l}\text { Temperature } \\
\text { (C) }\end{array}$ & $\begin{array}{l}\text { Time } \\
(\mathrm{min})\end{array}$ & & & \\
\hline \multicolumn{2}{|l|}{20 (Control) } & $\mathrm{t} 2$ & 2.1 & 31.0 \\
\hline & & Race 1 & 14.4 & 50.7 \\
\hline & & Hh 4 & 27.0 & 76.2 \\
\hline \multirow[t]{3}{*}{45} & 60 & $\mathrm{t} 2$ & 11.8 & 86.8 \\
\hline & & Race 1 & 36.7 & 60.2 \\
\hline & & Hh $4 \cdots$ & 31.4 & 81.9 \\
\hline
\end{tabular}

* Tested with H.E.S. 4.

** Treated $1 \mathrm{hr}$ before inoculation.

*** Refer to Table 1.

hyphae. Even if the resistant reaction was induced to some extent during the short period of association till the differentiation of secondary hyphae, races with lower affinity may have better chance to be accepted by cells of heat-treated leaves than by those of non-treated leaves. To test these posibilities, seedlings of H.E.S. 4 were predisposed at $45 \mathrm{C}-60 \mathrm{~min}$, inoculated with 3 different races, and subjected to estimation of the degree of induced susceptibility. The result is shown in Table 2 . It is evident that races with lower affinities could establish infection on heated leaves with much higher efficiency comparing with that of compatible race. Race $t 2$ was capable of infecting the heat-treated leaves as much as 5 times those of untreated control, while compatible race $\mathrm{Hh} 4$, in this experiment, revealed no statistically significant increase in the infection frequency after heat treatment. The secondary resistance was also interfered with by the heat treatment, as was observed in the marked elongation of secondary hyphae. The individual spores of $\mathrm{t} 2$ that had overcome the primary barrier elongated the secondary hyphae at the same rate as that of compatible race. Thus the elongation of secondary hyphae does not necessarily parallel to the ESH frequency. Despite the marked growth of secondary hyphae, however, no discernible colony was formed on the heated leaves excepting the compatible one.

\section{Durability of heat-induced susceptibility}

On the basis of the above, questions naturally follow would be whether the heatinduced susceptibility could ever be retained, and if so how long it would effectively last. Two incompatible combinations, Isonig-race 1 and Kobinkatagi-race $\mathrm{t} 2$, were employed in this experiment. Leaves of these cultivars were predisposed at $45 \mathrm{C}-60$ min and inoculated with conidia of respective race with a $3 \mathrm{hr}$ interval. The result is shown in Figure 1. Heat-induced suscpetibility, as assessed by ESH frequency, disappeared, in both cases, with the elapse of time after heat treatment. The rate of disappearance was exponential. Again the elongation of secondary hyphae did not change significantly during the experimental period. 


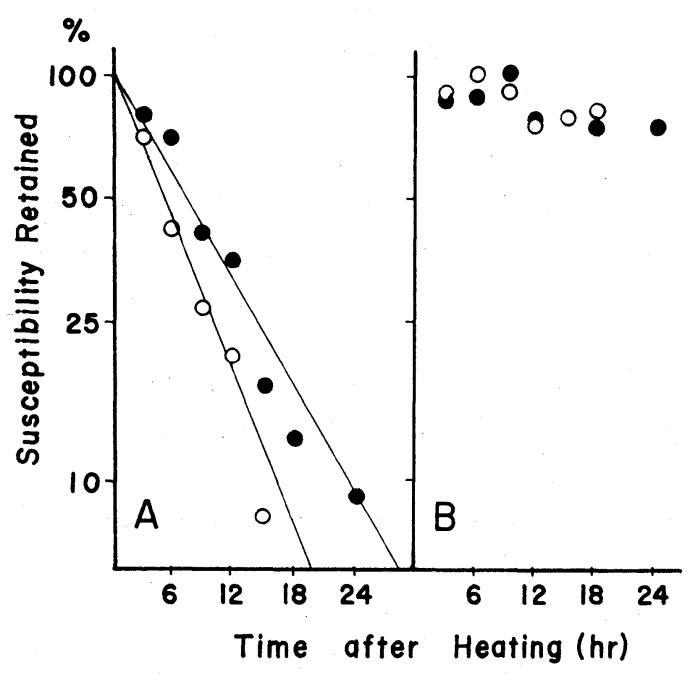

Figure 1. Rate of recovery of heat-impaired resistance as assessed with two different incompatible combinations.

Leaves were heat-treated and inoculated with respective incompatible race with a $3 \mathrm{hr}$ interval. Affinity indices were estimated $48 \mathrm{hr}$ after inoculation and percentages of retained susceptibility were calculated. A : ESH frequency; B: SH length; Open circle: Isonig-Race 1; Closed circle: Kobinkatagi-t 2 .

\section{Heat effect on compatible combination}

In order to elucidate whether compatible interactions are affected by the preliminary heat treatment, seedlings of Kobinkatagi were predisposed at various doses of heat, and were inoculated with conidia of race 1. Affinity indices and colony growth were estimated $48 \mathrm{hr}$ and 7 days respectively after inoculation. The result is shown in Table 3. ESH frequency increased significantly by the treatment at $45 \mathrm{C}$ and $50 \mathrm{C}$. Secondary hyphae elongation on leaves increased by predisposition at $45 \mathrm{C}$, but retarded at $50 \mathrm{C}$, Colony formation on leaves predisposed at $50 \mathrm{C}$ was slightly worse comparing to those of others, confirming the retardation of secondary hyphae on predisposition at higher doses.

Table 3. Effect of heat treatment on the infection establishment of a compatible combination*

\begin{tabular}{|c|c|c|c|c|}
\hline \multicolumn{2}{|c|}{ Heat Dosage } & \multirow{2}{*}{$\begin{array}{l}\text { Frequency } \\
(\%)\end{array}$} & \multirow{2}{*}{$\begin{array}{l}\text { SH length } \\
(\mu \mathrm{m})\end{array}$} & \multirow[b]{2}{*}{ Colony Formation** } \\
\hline $\begin{array}{l}\text { Temperature } \\
\text { (C) }\end{array}$ & $\begin{array}{l}\text { Time } \\
(\mathrm{min})\end{array}$ & & & \\
\hline \multicolumn{2}{|c|}{20 (Control) } & 43.9 & 109.9 & m \\
\hline 30 & 20 & 52.9 & 99.1 & 世 \\
\hline \multirow[t]{2}{*}{45} & 20 & 58.4 & 122.6 & m \\
\hline & 60 & 64.2 & 131.3 & m \\
\hline \multirow[t]{2}{*}{50} & 5 & 61.9 & 87.6 & m \\
\hline & 10 & 55.8 & 87.0 & 世 \\
\hline
\end{tabular}

* Tested with Kobinkatagi-Race 1 Combination.

** Estimated 7 days after inoculation. 


\section{Discussion}

Temperature effects are exerted directly or indirectly on the host cells or parasite, or more importantly on the complex, hence have been the subject of many articles and reviews $s^{1,7,10,28,30,35)}$. The thermal treatment above the suboptimal temperature breaks the immune type response of plants against varietal-nonpathogenic race or some nonpathogens, as have been referred to as 'heat-induced susceptibility', 'heat predisposition', or 'scalding effect'.

Salmon was the first to demonstrate that the detached leaves of Gramineae plants became susceptible to primarily incompatible race of Erysiphe graminis, when the leaves had been heated to $50 \mathrm{C}$ or touched with a hot knife ${ }^{21,22}$. Yarwood and his colleagues made extensive and critical analyses of the phenomena associated with heat predisposition $^{8,27 \sim 35)}$, and some others also reported general patterns of the heat-induced susceptibility with different host-parasite combinations ${ }^{10 \sim 12,15,24 \sim 26)}$. Another type approach to the heat effect with some host-parasite complex suggests that phytoalexins might possibly be involved in this heat-induced susceptibility ${ }^{2,5,6,9,17,20)}$.

The results in this paper extend previous information on temperature effect in powdery mildews. Heat treatment apparently rendered barley leaves susceptible to incompatible races at appropriate doses, but this induced susceptibility seemed to be inactivated at higher doses. The elongation of secondary hyphae was also retarded on leaves treated at $50 \mathrm{C}-10 \mathrm{~min}$ comparing with those treated at lower doses, suggesting that treatment at a dose level exceeding a certain limit disturds physiological processes associated with heat predisposition. Similar phenomenon was reported of the leaf rust of poplars ${ }^{26)}$ and the crown rust of oats ${ }^{25)}$.

A body of evidence has been accumulated to show that ESH frequency cannot be correlated with $\mathrm{SH}$ length ${ }^{14,18,19)}$. This fact strongly suggests that the all-or-none type decision as to acceptance or rejection of particular race is regulated at a different level from that concerned with the elengation of secondary hyphae. The result of the assessment of induced susceptibility with 3 races of different compatibilities indicated that although the primary barrier could be effectively broken by heat treatment, the race of low compatibility cannot establish infection as much as those of higher affinities. Thus races of low affinity, such as nonpathogen, seem to induce rejection reaction before the differentiation of the secondary hyphae, even though invaded cells had been conditioned to be affinitive to them by the heat treatment. Spores succeeded in conditioning of host cells toward symbiotic association were, however, capable of elongating secondary hyphae at a similar rate as that of compatible ones, at least in the early phase of infection. The absence of phytoalexin activity in leaves heat-treated and inoculated with incompatible race seems to rationalize this indifferent growth of secondary hyphae ${ }^{17)}$. Nevertheless no visible colony was formed on these predisposed leaves. Thus the heat-induced susceptibility described in this paper must be diffenrent from that reported by Salmon ${ }^{22}$, and suspected to be due to a temporary disorder of the regulatory system for resistance. This was indeed the case (Figure 1). The heatinduced susceptibility disappeared exponentially within about $24 \mathrm{hr}$ after treatment. This is extremely short in view of the heat-induced susceptibitities demonstrated in lima bean rust $^{8)}$ and tobacco mosaic disease ${ }^{29}$, which lasted as long as 5 days and 3 
days respectively. It is likely therefore that the heat-induced susceptibility dealt with in this paper differs from those observed in lima bean and tobacco. The rate of timedependent decrease of induced susceptibility follows the rate of pseudo first-order reaction kinetics. This fact suggests that the repair of resistance mechanism from heat damage occurs possiblly as an active process. In contrast to the definite decrease of ESH frequency, SH length was not retarded significantly, at least within $48 \mathrm{hr}$, as far as the spore could have established infection, again supporting the notion stated above.

A compatible combination was also affected by heat treatment. Leaves treated at appropriate thermal doses supported a significantly better growth of secondary hyphae comparing with those of untreated control. Again cells exposed to higher temperature seem to have resumed resistance. One of the plausible interpretations of heat-induced susceptibility in compatible combination would be that in natural infection even the compatible races are obliged to actively overcome an inherent and inducible resistance mechanism that has probably been acquired in the evolutionary process and is sensitive to suboptimal temperature.

Further analyses of heat-induced susceptibility will provide a clue to the formulation of molecular basis of primary recognition.

\section{Acknowledgement}

Authors are indebted to Professor U. Hiura for his kind supply of the isogenic line. Thanks are also due to Drs. H. Ikegami and T. Tani for their suggestions and criticism.

\section{Literature cited}

1) Bawden, F. C. (1955). J. Roy. Soc. Arts 103: 436-451.

2) Bell, A. A. and Presley, J. T. (1969). Phytopathology $59: 1141-1146$.

3) Browning, J. A. (1960). Ibid. 50:630 (Abst.).

4) Browning, J. A. (1960). Ibid. $50: 630$ (Abst.).

5) Chamberlain, D. W. (1972). Ibid. 62: 645-646.

6) Chamberlain, D. W. and Gerdemann, J. W. (1966). Ibid. $56:$ 70-73.

7) Fulton, R. W. (1967). Plant Virology (Corbett, M. K. and Sisler, H. D., ed.), 36-67, Univ. Florida Press, Gainsville, Florida.

8) Ikegami, H. (1968). Phytopathology $58: 773-775$.

9) Jerome, S. M. R. and Müller, K. O. (1958). Austr. J. Biol. Sci. 11: 301-314.

10) Kassanis, B. 1952 . Ann. Appl. Biol. 39: 358-369.

11) Klarman, W. L. (1965). Phytopathology $55: 505$ (Abst.).

12) Liu, S. C. Y. and Silberschmidt, K. M. (1961). Ibid. $51: 413-415$.

13) Luig, N. H. and Rajaram, S. (1972). Ibid. $62: 1171-1174$.

14) McKeen, W. E. and Bhattacharya, P. K. (1970). Can J. Botany 48: 1109-1113.

15) Mildenhall, J. P. and Williams, P. H. (1973). Phytopathology $63: 276-280$.

16) Mohamed, H. A. (1960). Ibid. $50: 33-340$.

17) Oku, H., Ouchi, S., Shiraishi, T., Komoto, Y. and Oki, K. (1975). Ann. Phytopath. Soc. Japan 41 : 185-191.

18) Ouchi, S., Oku, H., Hibino, C. and Akiyama, I. (1974). Phytopathol. Z. 79: 24-34.

19) Ouchi, S., Oku, H., Hibino, C. and Akiyama, I. (1974). Ibid. $79: 142-154$.

20) Rahe, J. E. and Kuć, J. (1970). Phytopathology. 60: 1005-1009.

21) Salmon, E. S. (1905). Phil. Trans. Roy. Soc. London B. 197 : 107-122. 
22) Salmon, E. S. (1905). Ann. Botany 19 : 125-148.

23) Staub, T. and Williams, P. H. (1972). Phytopathology $62: 722-728$.

24) Straib, W. and Noll, A. (1944). Zentr. Bakteriol. Parasitenk. Abt. II, 106 : 257-279.

25) Tani, T., Yamamoto, H., Onoe, T. and Naito, N. (1973). Tech. Bull. Fac. Agr., Kagawa Univ. $25: 53-59$.

26) Wagenbreth, D. (1968). Phytopathol. Z. 61: 88-97.

27) Yarwood, C. E. (1956). Phytopathology $46: 523-525$.

28) Yarwood, C. E. (1959). Plant Pathology (Horsfall, J. G. and Dimond, A. E., eds.), 521-562, Academic Press, New York.

29) Yarwood, C. E. (1963). Phytopathology 53: 1144 (Abst.).

30) Yarwood, C. E. (1965). World Rev. Pest Control 4: 53-63.

31) Yarwood, C. E. (1965)' Phytopathology 55: 1372.

32) Yarwood, C. E. (1966). Ibid. $56: 153$ (Abst.).

33) Yarwood, C. E. and Hooker, A. L. (1966). Ibid. 56: 510-511.

34) Yarwood, C. E., Ikegami, H. and Batra, K. K. (1969). Ibid. 59: 596-598.

35) Yarwood, C. E., Sidky, S., Cohen, M. and Santilli, V. (1954). Hilgardia 22 : 603-622.

\title{
和文 摘 要
}

\author{
オオムギうどんこ病における熱誘導感受性の特性について \\ 大内成志・奥 八 郎 \\ 中林英人 · 岡 和 德
}

らどんこ病に対する親和性を異にするオオムギ品種ならびに系統を用いて，接種前乾熱処理効果を調べ た。非親和の組合せの場合， $45 \mathrm{C}$ 以上の処理によって感染が成立するようになるが，その程度は組合せによっ て異なっていた。しかしいずれの組合せにおいても，50Cで10 分間処理することにより，一旦誘導された感 受性が低下した。またどの温度処理区においても肉眼で認められる程の菌丵形成はなかった。熱誘導感受性 は親和性の低いレースに対してょり有効であったが，しかしその感染成立頻度は親和性のそれに比較すると低 く, 非親和菌は少くとも第二次菌系伸長以前に細胞組織において拒否反応を誘導するものと考学られた。この 熱誘導感受性は処理後ほぼ 24 時間以内に消失し，その速度は一次反応に従がっていた。親和性の組合せにお いても同様な温度処理効果が認められ，45C 処理で感染成立頻度は高くなるが，50 C 10 分処理では再び低下 した。 